\title{
Antimicrobial Activity and Cytotoxic Effect on Gingival Cells of Silver Nanoparticles Obtained by Biosynthesis
}

\author{
BOGDAN ANDOR\#, ALINA ANDREEA TISCHER (TUCUINA)\#, DELIA BERCEANU-VADUVA, VOICHITA LAZUREANU*, \\ ADELINA CHEVERESAN, MARIOARA POENARU \\ Victor Babes University of Medicine and Pharmacy, Faculty of Medicine, 2 Eftimie Murgu Sq., 300041, Timisoara, Romania
}

\begin{abstract}
The emergence and development of biofilm is steadily increasing and its currently used prevention and control schemes are free of unwanted effects. Silver nanoparticles obtained through biosynthesis represent an area of interest in the biofilm approach. In the presentstudy, silver nanoparticles were obtained by using the aqueous extract of rosemary leaves which were subsequently tested for antimicrobial activity and for the influence regarding viability of healthy gingival cells. Experiments have shown a significant antimicrobial activity on $E$. coli, S. aureus, P. aeruginosa and C. albicans. The viability of keratinocytes and gingival fibroblasts was influenced by higher concentrations of test compound (10 and $25 \mu \mathrm{g} / \mathrm{mL}$ ).
\end{abstract}

Keywords: oral diseases, biofilm, green silver nanoparticles, antimicrobial, gingival cells

Currently, biofilms are assumed to be liable for a high percentage of infections ( $65 \%$ nosocomial infections and $\sim 80 \%$ of all microbial infections) [1]. The attachment of bacteria to a surface is a key step in the biofilm formation, especially regarding the influence on the cells - they become phenotypically different from their counterpartfree cells, and are more resistant to stress conditions [1]. Mostfrequently, related to biofilm are the following species: Enterococcus faecalis $(+)$, Staphylococcus aureus $(+)$, Staphylococcus epidermidis $(+)$, Streptococcus sp. $(+)$, Escherichia coli (-), Klebsiella sp (-), Proteus mirabilis (-), Pseudomonas aeruginosa (-), Candida albicans [1].

In the oral cavity, diseases associated with both the mouth and the dental surface, such as: gums or periodontium - related to dental disorders; abnormal changes in natural microflora and breath - related to teeth; wounds and pain, neck or oral cancer, trauma from injuries and oral infectious diseases-related to mouth, are frequently reported $[2,3]$. In terms of the occurrence and incidence of dental diseases, bacteria are mostly liable and once the disease is installed, drug treatment is mandatory. An important aspect to be taken into account is that of the existence of other pathologies (diabetes, AIDS, other autoimmune diseases, and even also metallic implants) and their severity because selecting the optimal treatment becomes very difficult [4]. In the case of maxillofacial surgery most of the time occur bone defects which associated with previously described problems impedes the application of effective treatment in biofunctional and aesthetic restoration [5]. On the other hand, if the pathogens remain untreated can cause a number of complications such as: diabetes, cardiac disorders, osteoporosis, pneumonia, stroke etc. [6-10]. The most common method of treatmentincludes the administration of antibiotics but, they lead to a number of unwanted effects like systemic side effects and the disruption of the normal microbial flora with an increase regarding microbial resistance [2].

An area of great interest at present is that of nanotechnology. Silver nanoparticles exert significant antibacterial and antiviral activities, being able to interact with differentmicroorganisms, thereby reducing the growth and maturation of biofilm [11]. There are studies regarding the toxicity of silver nanoparticles and samples with a spherical shape, and size between $10-50 \mathrm{~nm}$ are presented as a safe profile for healthy cells in terms of viability and in terms of acute/subacute toxicity on an animal model no denotive changes regarding health status after i.p. administration of low doses was observed [12]. Plants are an endless source of compounds with remarkable biological activity [13]. Application of biosynthesis in the case of silver nanoparticles with various pharmacological properties are possible due to the resources from the natural environment and presents a number of advantages, among which: environment friendly, economical effective and easy production [14].

The main purposes of the current study are: a) biosynthesis of silver nanoparticles by using an aqueous leaves rosemary extract, b) evaluation of antimicrobial activity by disk diffusion method and c) assessment of cytotoxicity on healthy gingival cells, keratinocytes and fibroblasts, by MTT assay.

\section{Experimental part}

Materials and methods

All the substances utilized in the current study were of analytical grade and purchased from Sigma Aldrich, Germany. Rosmarinus officinalisleaves were acquired from natural local market, Timisoara, Romania.

\section{Synthesis of green silver nanoparticles (RAE AgNPs)}

An aqueous rosemary leaves extract (RAE) was prepared: $10 \mathrm{~g}$ dry plant material were boiled in $100 \mathrm{~mL}$ distilled water for $3 \mathrm{~min}$, cooled to room temperature, filtered, centrifuged $10 \mathrm{~min}$ at $4000 \mathrm{rpm}$. The fresh separated supernatant was utilized as reducing and stabilizing agent in the synthesis of silver nanoparticles: aqueous $\mathrm{AgNO}_{3}(1 \mathrm{mM})$ was added to $50 \mathrm{~mL}$ of extract and then the mixture was introduced in an orbital shaker, in dark, for $48 \mathrm{~h}, 250 \mathrm{rpm}$, at room temperature. For purification, the final solution was centrifuged at 10000 $\mathrm{rpm}$, washed with deionized water and suspended in $\mathrm{EtOH}$ $96 \%$. The first indicator of silver nanoparticles formation is the change of colour from brown to clear yellow. Blank sample (without silver nitrate) were prepared in the same conditions. 
In vitro activity of $R A E$ AgNPS

RAE_AgNPs Antimicrobial activity (AMA)

Green silver nanoparticles were evaluated by disk diffusion (DD) method for AMA against Staphylococcus aureus (+ , ATCC 25923), Escherichia coli (-, ATCC 25922), Pseudomonas aeruginosa (-, ATCC 27853), and Candida albicans (fungi, ATCC 10231). The experiments were conducted in specific plates, positive controls used were Gentamicin and Nystatin, and negative control aqueous alcoholic solution. There were made dilutions ( $10^{-3}$ for bacteria and $10^{-2}$ for fungi cultures) in order to realize the tests and the Petri plates were seeded and the chosen specimens were treated with the RAE AgNPs $(0.1,1,5$, 10 , and $25 \mu \mathrm{g} / \mathrm{mL}$ ) and incubated at different temperature $\left(30^{\circ} \mathrm{C}\right.$ for fungi and $37^{\circ} \mathrm{C}$ for bacteria), for $24-48 \mathrm{~h}$. The experiments were realized in triplicate.

RAE AgNPs effect on gingival keratinocytes and fibroblasts viability

The cell lines used in this study: PGK - primary gingival keratinocytes (ATCC $®$ PCS-200-014 ${ }^{\mathrm{TM}}$ ) and HGF - primary gingival fibroblasts (ATCC ${ }^{\circ}$ PCS-201-018 ${ }^{\text {TM }}$ ) were purchased as frozen samples and kept in liquid nitrogen until the start of the tests. All the specific media and reagents required for cell cultivation were ordered atSigma Aldrich (Germany). The activity of RAE AgNPs on cells viability was evaluated on normal gingival $\bar{c}$ ells. The culture method utilized was according to the ones describe in the literature, and to assess the viability of the cells a colorimetric test (MTT method) was conducted and applied [15]. Shortly, $10^{4}$ cells/well were seeded onto a 96-well plate in specific media and incubated until $90-95 \%$ confluence was reached and after stimulated with media containing $0.1,1,5,10$, and $25 \mu \mathrm{g} / \mathrm{mL}$ of RAE AgNPs.

\section{Statistical data}

The Graph Pad Prism 7 was utilized for data processing along with one-way ANOVA followed by post-test to establish the statistical differences between groups.

\section{Results and discussions}

The RAE_AgNPs were characterized by well-known methods, and the data regarding their characteristics are presented in table 1.

Silver has been used since antiquity for its therapeutic effects, but the exact mechanism of action is still at the stage of debate. It is recognized that the antimicrobial potential is due to the positive loading of the silver ion therefore, the form used must be ionized. Even if in this form is inert, when it comes in direct contact with the biological media releases silver ions which interact with nucleic acids [14].

The AMA of biosynthesized silver nanoparticles was evaluated against different Gram positive bacteria, Gram negative bacteria and fungi by DD method. The data obtained are presented in table 2 and are expressed as diameter (mm) of inhibition zone (IZ) and includes the disc diameter, $6 \mathrm{~mm}$. The values showed that RAE AgNPs, utilized in concentration of $0.1,1,5,10$, and $25 \mu \mathrm{g} / \overline{\mathrm{m}} \mathrm{L} / \mathrm{disk}$, presents an important antimicrobial activity: the most accentuated effect was recorded at the highest concentration tested, as expected, against $E$. coli $(26 \mathrm{~mm}$ at $25 \mu \mathrm{g} / \mathrm{mL}$ ). Neither the effects exerted against $S$. aureus nor $P$. aeruginosa are negligible given that they are much higher than the positive control used.

Based on the increasement of test compounds concentrations, the shape of the cells is influenced in different manner. Primary gingival keratinocytes, have an epithelial morphology, with some round form, cobblestone appearance and strong adhesion qualities which athighest concentrations utilized $(5,10$, and $25 \mu \mathrm{g} / \mathrm{mL})$ lose their shape and viability, as can be observed in figure 1 . The same observations can be made in the case of fibroblasts: they have a spindle prolonged form, are not adherent to culture plate, having the ability to migrate; after stimulation with test compounds at 10 and $25 \mu \mathrm{g} / \mathrm{mL}$ their properties are affected (fig. 1).

Cell viability tests are an important stage in toxicological assessments of new treatment approach and can offer significant data regarding cell death, metabolic activity and cell survival. The RAE AgNPs were tested in order to establish their effect in tērms of viable cells, on two healthy gingival cell lines, keratinocytes and fibroblasts. As can be seen in figure 2, the effect exerted depends on the tested
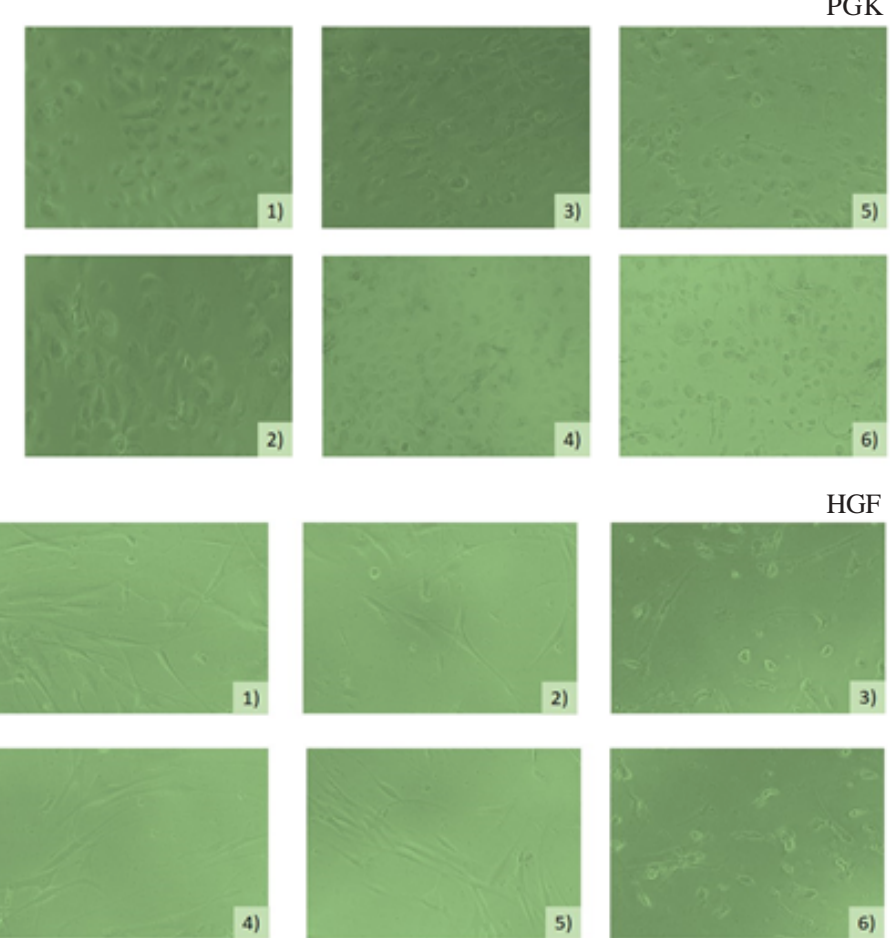

Fig.1 Influence of RAE_AgNPs ( 1 - control; 2 - $0.1 \mu \mathrm{g} / \mathrm{mL} ; 3$ - $1 \mu \mathrm{g} / \mathrm{mL} ; 4$ $5 \mu \mathrm{g} / \mathrm{mL} ; 5-10 \mu \mathrm{g} / \mathrm{mL}$ and $6-25 \mu \mathrm{g} / \mathrm{mL}$ ) on primary gingival keratinocytes and human gingival fibroblasts cells form

\begin{tabular}{|l|l|l|}
\hline Sample & Technique & Data \\
\hline RAE_AgNPs & TEM & $72 \mathrm{~nm} \pm 5$ (S.D.), spherical shape \\
\hline RAE_AgNPs & DLS & $132 \mathrm{~nm} \pm 4$ (S.D.) in deionized water, $145 \mathrm{~nm} \pm 5$ (S.D.) in culture media \\
\hline RAE_AgNPs & Zeta & $-30 \mathrm{mV}$ in deionized water, $-22 \mathrm{mV}$ in culture media \\
\hline
\end{tabular}

\begin{tabular}{|c|c|c|c|c|c|c|}
\hline & \multicolumn{4}{|c|}{$R A E_{-} A g N P s$} & & \multirow{2}{*}{$\begin{array}{l}\text { Positive } \\
\text { control }\end{array}$} \\
\hline & $0.1 \mu \mathrm{g} / \mathrm{mL}$ & $1 \mu \mathrm{g} / \mathrm{mL}$ & $5 \mu \mathrm{g} / \mathrm{mL}$ & $10 \mu \mathrm{g} / \mathrm{mL}$ & $25 \mu \mathrm{g} / \mathrm{mL}$ & \\
\hline S. aureus $(+)$ & $12 \mathrm{~mm} \pm 0.58$ & $15 \mathrm{~mm} \pm 0.52$ & $18 \mathrm{~mm} \pm 0.37$ & $20 \mathrm{~mm} \pm 0.71$ & $24 \mathrm{~mm}=0.49$ & $15 \mathrm{~mm}$ \\
\hline E coli $(-)$ & $12 \mathrm{~mm} \pm 0.30^{\circ}$ & $16 \mathrm{~mm}=0.42$ & $19 \mathrm{~mm} \pm 0.61$ & $23 \mathrm{~mm} \pm 0.36$ & $26 \mathrm{~mm}=0.28$ & $12 \mathrm{~mm}$ \\
\hline P. aeruginosa (-) & $9 \mathrm{~mm}=0.21$ & $11 \mathrm{~mm}=0.56$ & $16 \mathrm{~mm} \pm 0.43$ & $19 \mathrm{~mm} \pm 0.50$ & $21 \mathrm{~mm}=0.22$ & $15 \mathrm{~mm}$ \\
\hline C. albicans & $8 \mathrm{~mm} \pm 0.34$ & $9 \mathrm{~mm} \pm 0.28$ & $12 \mathrm{~mm} \pm 0.36$ & $14 \mathrm{~mm} \pm 0.22$ & $17 \mathrm{~mm}=0.64$ & $12 \mathrm{~mm}$ \\
\hline
\end{tabular}

Table 1 CHARACTERIZATION OF SILVER NANOPARTICLES OBTAINED BY BIOSYNTHESIS

Table 2

AMA OF THE GREEN SILVER NANOPARTICLES CONDUCTED BY DD METHOD, $M E A N \pm S . D$ 


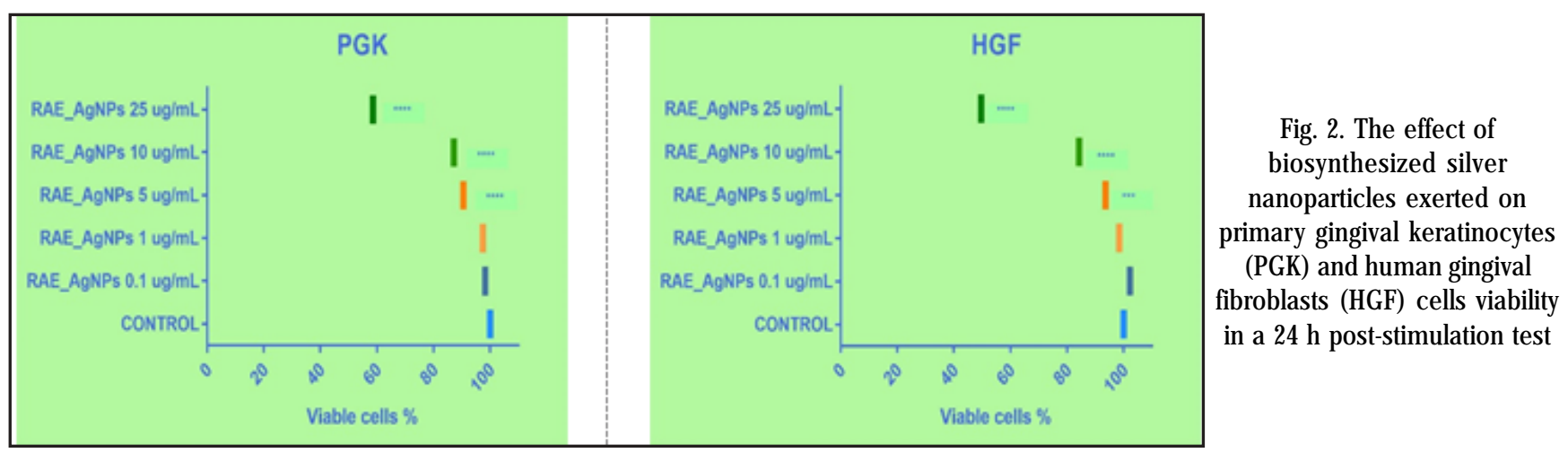

dose: at low concentrations there is no notable effect on cell viability $(0.1$ and $1 \mu \mathrm{g} / \mathrm{mL}$ for gingival keratinocytes and $0.1,1$ and $5 \mu \mathrm{g} / \mathrm{mL}$ for fibroblasts) while with the increasing of the dose it can be seen an increase in the percentage of dead cells, especially at the highest concentration used $(25 \mu \mathrm{g} / \mathrm{mL})$.

\section{Conclusions}

The biosynthesized silver nanoparticles were obtained with an aqueous leaves extract of rosemary. The formation of nanoparticles during the synthesis was investigated spectrophotometrically, taking into account the visible color change, and the size and stability of the nanoparticles was confirmed by SEM, DLS and zeta potential measurements. The data resulted from antimicrobial activity evaluation revealed that RAE AgNPs biosynthesized in this study exert an efficient AMMA against all tested strains, $S$. aureus, E. coli, $P$. aeruginosa and $C$. albicans, with the most pronounced activity on $\mathrm{E}$. coli. The viability of healthy gingival cells, evaluated by MTT assay, is significantly influenced only at concentrations higher than $10 \mu \mathrm{g} / \mathrm{mL}$. Silver nanoparticles obtained by green synthesis using plant extracts are optimal candidates which is mandatory to be exploited to the maximum in terms of preventing and combating biofilms.

\section{References}

1. HOLBAN, A.M., GESTAL, M.C., GRUMEZESCU, A.M. International Journal of Pharmaceutics 510, 2016, 409-418.

2. FERNANDES

3. SARAU, C.A., POENARU, M., BALICA, N.C., BADERCA, F. Rom J Morphol Embryol 58(4), 2017,1541-1547.
4. PATRASCU, J.M., VERMESAN, D., MIOC, M.L., LAZUREANU, V., FLORESCU, S., TARULLO, A., et al. EUROPEAN REVIEW FOR MEDICAL AND PHARMACOLOGICAL SCIENCES 18(24), 2014, 3898-3901.

5. GABOR, A., HOSSZU, T., ZAHARIA, C., KOZMA, A., COJOCARIU, A.C., NEGRUTIU, M.L., et al. Mat.Plast., 54, no.1, 2017, p.29-31.

6. HOLMSTRUP, P., FLYVBJERG, A., Oral Infections and General Health: From Molecule to Chairside. Springer International Publishing, Cham, 2016, 35-44.

7. LAURENCE, B., MOULD-MILLMAN, N.K., SCANNAPIECO, F.A., ABRON, A. Clin. Oral Invest. 19, 2015, 1261-1268.

8. LOCKHART, P.B., BOLGER, A.F., PAPAPANOU, P.N., OSINBOWALE, O., TREVISAN, M., LEVISON, M.E., et al. 2012. Circulation 25(20), 2012, 2520-2544

9. PALM, F., PUSSINEN, P.) ., AIGNER, A., BECHER, H., BUGGLE, F., BAUER, M.F., et al.2016. Atherosclerosis 254, 2016, 117-123.

10. WANG, C.J., MCCAULEY, L.K., 2016. Curr. Osteoporos. Rep. 14, 2016, 284-291.

11. FRANCI, G., FALANGA, A., GALDIERO, S., PALOMBA, L., RAI, M., MORELLI, G., GALDIERO, M., 2015. Molecules 20(5), 2015, 8856-8874. 12. PINZARU, I., CORICOVAC, D., DEHELEAN, C., MOACA, E.A., MIOC, M., BADERCA, F., et al. FOOD AND CHEMICAL TOXICOLOGY 111, 2018, 546-556.

13. ANDOR, B., DANCIU, C., ALEXA, E., ZUPKO, I., HOGEA, E., CIOCA, A., et al. Evid Based Complement Alternat Med. 2016, 2016, 7638542. 14. AHMED, S., AHMAD, M., SWAMI, B.L., IKRAM, S. J ournal of Advanced Research 7, 2016, 17-28.

15. CORLAN, I.V., CHEVERESAN, A., BERCEANU VADUVA, D., NICA, C., FAUR, A.,

RUMEL, R.C., RAMONA AMINA POPOVICI, R.A. Rev.Chim.(Bucharest), 69, no.10, 2018, p.2891-2894.

Manuscript received: 21.12 .2018 